\title{
UMA PRÁTICA ANTROPOLÓGICO-TERAPÊUTICA NO (E COM $O$ ) ACASO: O TRABALHO DE CAMPO EM QUESTÃO*
}

\author{
Carolina Tamayo \\ Diego de Matos Gondim
}

Ceux qui n'ont pas été pris, ils ne peuvent parler

Jeanne Favret-Saada (1977)

O trabalho de um antropólogo, a despeito do tema declarado, tende a ser uma expressão de sua experiência de pesquisa, ou, mais precisamente,

do que a experiência de pesquisa faz a ele.

Clifford Geertz (1968)

\section{Nota ao leitor}

\section{Tono $I$-Aberturas}

O trabalho de campo e a prática etnográfica têm sido discutidos de forma abrangente nas áreas de Educação e de Educação Matemática nos últimos anos. Ainda que na segunda de forma mais tímida, de um ponto de vista geral, estas discussões consideram as diversas interlocuções que, tanto a Educação quanto a Educação Matemática, vêm historicamente estabelecendo com a Antropologia e a Sociologia, tendo em conta que o trabalho de campo e a prática etnográfica se tratam de uma atividade de investigação e produção de dados habitual destas áreas de pesquisa ${ }^{1 .}$

\footnotetext{
* DOI - 10.29388/978-65-86678-51-2-0-f.273-296

${ }^{1} \mathrm{Na}$ Educação, os trabalhos produzidos formam uma grande constelação. Portanto, citamos a obra "Etnografia e educação: conceitos e usos", de Mattos e Castro (2011). Esta obra, a nosso ver, traz uma dimensão não apenas de "estado da arte" dos vínculos da Educação com a prática etnográfica (o que pode ser visto nos primeiro e segundo capítulos), mas também uma apresentação deste uso em problemas específicos da Educação, como a problematização da sala de aula, dos conceitos de ensino, aprendizagem, entre outros. Na Educação Matemática, os trabalhos que enveredam por estas discussões são, muitas vezes, os que se ocupam da Etnomatemática. No entanto, a partir de uma busca nos bancos de dados, percebemos que não são muitos os trabalhos que tenham como centralidade de discussão as relações entre
} 
No séculos XIX e XX, com a institucionalização da Antropologia como Ciência Social, as descrições sobre experiências humanas e culturais, de povos e culturas distintas, passam a considerar a pessoa do antropólogo em seu lugar discursivo. Porém, é preciso não perder de vista, como apontam Marcus e Cushman (2003) no balanço crítico da produção etnográfica contemporânea, que a categoria "etnografia" tem sido utilizada de diversas maneiras ao longo das produções da Antropologia. Dada esta multiplicidade de usos, na Educação, ela vem sendo assumida enquanto método qualitativo de pesquisa, produzindo uma estratégia de elaboração do trabalho de campo em formas de diálogos estabelecidos entre os sujeitos envolvidos na pesquisa e o educador, ou como uma categoria de pensamento.

No que diz respeito ao discurso antropológico, durante muito tempo acreditavase que a prática etnográfica correspondia à procura da explicação dos costumes de um povo e, além disto, que tais explicações eram isentas de juízos de valor do etnógrafo. Isto porque, acreditava-se na possibilidade de o "estrangeiro" observar o "objeto", sendo este o "outro". O que estes discursos não tomaram em conta é que, primeiro, o que se observa não são objetos, mas sujeitos ativos em suas próprias formações subjetivas e discursivas; segundo, que a simples presença do "estrangeiro" altera, por mínima que seja, a dinâmica destes sujeitos; e, por fim, que a categoria "outro" não se aplicava apenas aos sujeitos envolvidos na prática etnográfica, mas também ao estrangeiro, sendo este o "outro" enquanto presença. Em sua generalidade, tais “interlocuções” visavam a compreensão das dinâmicas da sociedade através do uso da explicação, em sua produção multifacetada de subjetividades e de relações de forças dilatadas numa malha de poder (estabelecidas pelas dualidade dicotômica Eu/Outro) que procura expressar como indivíduos (se) organizam (n)o mundo.

Neste contexto de produção de entendimentos da cultura do "outro", o teórico linguístico Kenneth Pike, em 1954, cunha os termos emic e etic como base epistemológica da etnografia no marco dos estudos vinculados ao materialismo cultural ${ }^{2}$. Pike argumenta que esta distinção possibilitaria, na linguística, a interpretação do sujeito (fonema) frente à realidade acústica de um som (fonética). Em termos gerais, emic (como em phonemics fonologia) se refere aos conhecimentos subjetivos e aos seus significados, considerando os sons da língua, ou seja, preocupa-se principalmente com a acústica, propriedades externas e significados das palavras. Em complementação, etic (como em phonetics - fonética) se refere ao estudo objetivo desses sons, ou seja, pertence ao estudo de sons universalmente utilizados na

Etnografia e Educação Matemática e/ou Etnomatemática. Como exemplo destes trabalhos, citamos a comunicação apresentada no último Congresso Internacional de Etnomatemática (Colômbia), realizada por Parra e Tamayo (2018). Neste trabalho, as relações de saber/poder da Etnografia na Etnomatemática são propósitos de problematização dos autores. Mais especificamente, citamos também os trabalhos de Tamayo-Osorio (2017) e Gondim (2020). Nestes dois últimos, os autores se ocupam diretamente do trabalho de campo e de questões da etnografia para problematiza-las enquanto prática "comum” na Etnomatemática.

2 Kenneth Pike, ao participar do Summer Institute of Linguistics (SIL), promove a alfabetização em língua indígena na América Latina como parte do processo de evangelização através da oficialização de programas de educação indígena bilíngue. Barros (1994), em seu texto intitulado "Educação Bilíngue, Linguística e Missionários”, traça uma história da concepção de linguística como ciência aplicada da Educação Indígena na América Latina. Em sua perspectiva, não é possível se referir aos modelos de educação indígena bilíngue sustentado em bases linguísticas sem fazer menção aos missionários do SIL, pois a pesquisadora analisa a "proposta de educação na língua indígena na América Latina foi uma posição compartilhada por missionários e indigenistas. Os indigenistas viram no projeto educativo bilíngue o método mais eficiente para o ensino da língua nacional (Castillo, 1945, p.140). Para os missionários, a educação bilíngue é parte do processo de conversão, onde a alfabetização na língua indígena é condição da tarefa evangelizadora” (Ibid., p. 29). 
linguagem humana, tendo como especificação a função dos sons dentro de uma língua independentemente de seus significados. Nas palavras de Kenneth Pike (1967, p. 37):

It proves convenient -through partially arbitrary to describe behaviour form two different standpoints, which lead to results which shade into one another. The etic viewpoint studies behaviour as from outside of a particular system, and as an essential initial approach to an alien system. The emic viewpoint results from studying behaviour as from inside the system. (I coined the words etic and emic from the words phonetic and phonemic, following the conventional linguistic usage of these latter terms. The short terms are used in an analogous manner, but for more general purposes) $)^{3}$.

Neste sentido, para o autor, a linguagem é heterogênea, ao passo que a língua é considerada um sistema de signos de natureza homogênea, existente na coletividade e exterior ao indivíduo, que por si só não pode criá-la nem a modificar. Assim, a linguagem é considerada exterior ao sujeito. Nesta direção, é importante ressaltar que os behavioristas postulam que a linguagem é apenas uma convenção social e sua aquisição é processada por condicionamento e/ou memorização.

Posteriormente, em 1967, ao expandir a compressão dicotômica entre emic/etic em seu livro Linguagem em relação a uma teoria unificada da estrutura do comportamento bumano, Kenneth Pike esclarece que esta dicotomia é utilizada nos estudos do comportamento humano como uma analogia entre os 'observadores de dentro' e os 'observadores de fora'. Por isto, em sua concepção, a abordagem etic se refere a uma interpretação de aspectos de outra cultura a partir das categorias daqueles que a observam, tomando em conta que o observador está "fora" do sistema em questão. Por outro lado, a abordagem emic procura compreender determinada cultura com base em seus próprios referenciais. Por isto, temse em conta que o observador está “dentro" do sistema em questão.

Esta perspectiva teórica - emic/etic - contribuiu com a legitimação de uma forma de praticar a etnografia no âmbito dos estudos antropológicos. Dentre as inúmeras práticas, encontra-se a legitimação de sistemas explicativos das crenças de povos não europeus, tendo como base a racionalidade europeia (dos colonizadores); encontra-se também a invisibilização epistêmica dos povos, assumidos na vasta bibliografia como "primitivos" e, portanto, portadores de uma oralidade que deveria ser transformada em escritura. Nesta distância, onde salta a dicotomia oralidade/escritura, a invisibilização ocorre em uma prática de observação do "outro" que não tem por finalidade incluir a oralidade como parte definidora da cultura dos povos "primitivos", mas reduzir reduzí-la no estabelecimento de padrões linguísticos da escrita colonial ${ }^{4}$. Em distintos contextos, tais práticas tinham como fundamento (desde a evangelização até a educação dos povos) um

\footnotetext{
3 “É conveniente - embora parcialmente arbitrário, descrever o comportamento de dois pontos de vista diferentes, que levam a resultados que se confundem. O ponto de vista etic estuda o comportamento de fora de um sistema particular e como uma abordagem inicial essencial para um sistema estranho. O ponto de vista emic resulta do estudo do comportamento a partir do sistema. (Eu criei as palavras etic e emic a partir das palavras fonética e fonêmica, seguindo o uso linguístico convencional desses últimos termos. Os termos curtos são usados de maneira análoga, mas para propósitos mais gerais)" (PIKE 1967, p. 37).

${ }^{4}$ Um exemplo pertinente para esta discussão se trata da obra "Les discours antillais", de Édouard Glissant (1997), onde o autor problematiza os processos de "criolização" por meio da transformação da linguagem.
} 
projeto estritamente colonial, onde era a escrita, enquanto instância fono-logo-cêntrica, a forma privilegiada para conservação da cultura.

No livro "O efeito etnográfico e outros ensaios", Marilyn Strathern problematiza as diferentes formas em que tem sido praticada a etnografia, ressaltando que a antropologia do século XIX se tornou especialista em "povos primitivos". Tal antropologia, segundo a autora, analisava o modo como estes povos se constituíam a partir de materiais de campo, como relatos de viajantes, de expedições científicas, dos missionários ou informes das oficinas coloniais. Os antropólogos que encenam esta época trabalhavam em seus gabinetes junto a estes materiais, lendo-os, deduzindo e especulando como as culturas "primitivas" se constituíam culturalmente. Para Strathern (2014), o êxito do estilo da produção destes antropólogos era apenas "funcionalista". Este funcionalismo tinha como base "tirar do contexto" as produções epistêmicas dos povos indígenas por eles estudados, fazendo uso de sistemas explicativos e descritivos que correspondem às categorias do pensamento ocidental.

Em uma entrevista realizada com Fiori et all. (2015, p. 12), a antropóloga britânica Marilyn Strathern pondera sua concepção de descrição etnográfica, apresentada no percurso da sua obra, do seguinte modo:

Eu, por outro lado, tendo a pensar... e talvez eu esteja errada no que diz respeito a meu próprio uso... mas eu acho que tendo a não usar esse termo [descrição etnográfica]; tendo a falar em etnografia, em descrição. Quando falo em etnografia, acho que utilizo o termo de forma muito geral, apenas para invocar o que tomamos por certo como o tipo de meio através do qual as coisas que observamos tornam-se o foco da análise. Mas quando utilizo a palavra descrição, essa é uma palavra bastante pesada para mim, pois en consideraria a descrição como o resultado final daquilo que fazemos, e não o começo. E considero que a descrição subsome tanto a análise quanto uma suposição teórica, de modo que é necessário realizar um trabalho imenso antes que se possa descrever qualquer coisa. Ao passo que utilizo "etnográfico" de forma muito... sabe, há algumas palavras nas quais nos concentramos; em outras não. Não tenho certeza... Talvez você tenha evidências melhores, das quais possa se lembrar melhor do que eu.

Deste modo, Strathern (2014) apresenta para o mundo acadêmico o fato de as etnografias serem construções analíticas de acadêmicos que tendem aos propósitos do seu tempo. Algumas das formas de desenvolvimento dessas construções analíticas são naturalizadas e, neste processo, são produzidas perspectivas onde os povos estudados são concebidos como construções analíticas. Por outro lado, junto à problematização de Strathern (2014), entendemos que o trabalho de campo, bem como as narrativas e descrições nele produzidas, devem assumir o fato de que existem coisas que não podem e nem precisam ser explicadas. Coisas estas que são composições de uma vida em produção a-significada.

Dito isto, é parte do exercício da experiência de campo, tanto quanto do exercício da pesquisa, reconhecer que uma forma de vida está além (au-delà) daquilo que pode ser compreendido por qualquer análise, seja qual for seu método de estudo. Por isto, não podemos almejar uma pretensão explicativa totalizante que tenha por fundamento o esgotamento da potencialidade simbólica das práticas e conhecimentos produzidos por uma dada cultura. Neste sentido, há então uma responsabilidade epistemológica e 
metodológica de colocar em questão as impossibilidades da etnografia, do ponto de vista antropológico, do que seria estar plenamente "dentro" ou inteiramente "fora" das formas de vida. Pela mesma razão - embora seja necessário apresentar os argumentos através de um conjunto de materiais históricos e geográficos proporcionados pelas culturas e sociedades com as quais pesquisadores interagem - é também necessário problematizar, junto a outras áreas do conhecimento, as aspirações que a compreensão etnográfica pode e não pode, tendo em conta a almejada transmissão de uma complexidade epistêmica das formas de vida que têm como referência o contexto particular em que estas são produzidas.

Neste sentido, Strathern (2014) esclarece que é necessário quebrar com as dicotomias que lidam com os modos como construímos nossas formas de conhecimento sobre outros coletivos e, simultaneamente, sobre nós mesmos. É através da "conexão parcial" engendrada pelo antropólogo - em uma escrita que conecta e explicita diferenças - entre um pensamento outro e o pensamento ocidental que estas perspectivas "incomensuráveis", em uma relação simétrica e "prostética", estendem as potencialidades imaginativas de nosso pensamento (STRATHERN, 2014). É a partir de uma relação como esta que Strathern (2014) confere legitimidade e reconhecimento à existência de uma "antropologia" outra, ou de praticar uma antropologia. Em síntese, poderíamos dizer que este outro modo de fazer antropologia não se fundamenta na explicação do outro, sequer do estabelecimento destas figuras representativas Eu/Outro, mas de criar uma rede de semelhanças ${ }^{5}$ que visa estender nossa compreensão do mundo produzindo outros mundos. Assim, tal prática antropológica não se baseia em um exercício de falar sobre e/ ou pelo outro, mas com, onde as dualidades representativas do sujeito se deslocam para a produção de um nós em completa conexão.

Dito isto, é nosso interesse neste texto aproximarmos da abordem da linguagem que o filosofo austríaco Ludwig Wittgenstein faz em seu livro "Investigações Filosóficas" - IF -. Nesta obra, o filósofo concebe a linguagem enquanto atividade dentro de forma de vida, com a qual o conceito de significação das palavras envolve o uso prático da linguagem e cria margens para tensionar a visão da linguagem promovida pelas perspectivas que assumem a visão emic/etic. O próprio Wittgenstein esclarece: “Was bezeichnen nun die Wörter dieser Sprache? - Was sie bezeichnen, wie soll ich das zeigen, es sei denn in der Art ihres Gebrauchs? Und den baben wir ja beschrieben" ". A linguagem, nesta perspectiva, não pode ser compreendida por meio de algum sistema puramente lógico-formal, mas no (e pelo) seu uso. É ele a diretriz que orienta a compreensão da linguagem, tendo em vista que ela é uma ação, retratada através da concepção de jogos de linguagem, onde "soll hier hervorheben, daß das Sprechen der Sprache ein Teil ist einer Tätigkeit, oder einer Lebensform" " Uma tal perspectiva possibilita compreender que não há como encaixar as manifestações da linguagem, em suas

\footnotetext{
5 "Eu não poderia caracterizar melhor essas semelhanças do que pela expressão "semelhanças de família"; pois assim se sobrepõem e se cruzam as distintas semelhanças que têm lugar entre os membros de uma família: altura, traços faciais, cor dos olhos, andar, temperamento etc., etc. - E eu direi: os 'jogos' conformam uma família. E do mesmo modo conformam, por exemplo, os tipos de número uma família. Por que chamamos algo de "número"? Ora, talvez porque haja um parentesco - direto - com muita coisa que se tem até aqui chamado de número; e, por isso, pode-se dizer que há também um parentesco indireto com outras coisas que também chamamos assim. ampliamos nosso conceito de número assim como, ao tecer uma fibra, enroscamos fio por fio. E a força da fibra não consiste em que algum fio percorra toda a sua extensão, senão em que muitos fios se sobrepõem mutuamente”. (WITTGENSTEIN, 2017, §67).

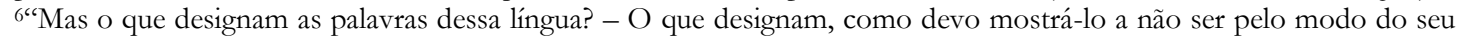
uso? E nós até o descrevemos". (WITTGENSTEIN, 2007, \$ 10).

7"A expressão "jogo de linguagem" deve enfatizar aqui que o falar de uma línguagem é parte de uma atividade ou de uma forma de vida” (WITTGENSTEIN, 2007, \$23).
} 
diversas formas humanas de vida, tendo como base concepções a priori fixas, sendo elas uma única estrutura e gramática que justifique seus usos.

$\mathrm{Na}$ contramão das perspectivas que desenvolvem suas pesquisas tendo como base a dicotomia emic/etic, Wittgenstein (2017) conceberá que a linguagem deve ser analisada a partir da descrição de semelhanças de família e diferenças entre seus diversos usos. Neste sentido, a linguagem não é exterior ao sujeito, pois cumpre uma função ativa nos processos individuais e coletivos que enredam a vida social.

Além do mais nos aproximamos da prática antropológica de Jeane Favret-Saada que parte do pressuposto de um "être affectê", onde não existe possibilidade de distinguir quem ou o que está fora ou dentro; as coisas se coengendram, se misturam sem se confundir umas nas outras. Tudo, em sua perspectiva, perpassa por uma produção sensível deste ser afetado que é, para ela, uma oportunidade para repensar as produções etnográficas, seja do ponto de vista metodológico e/ou epistemológico. Para a antropóloga, estar em campo é um envolvimento afetivo constituinte do etnógrafo e dos sujeitos que compõem aquele espaço. Portanto, a experiência vivida escapa à representações, categorizações e generalizações postuladas por teorias antropológicas que se estabelecem epistêmicametodologicamente a priori. Então, o que está em jogo em sua etnografia, trata-se de um movimento de desestruturação das dicotomias do pensamento ocidental para a constituição de uma prática antropológica do acaso.

Tendo em vista esta possibilidade de produção de uma pesquisa antropológica que visa mobilizar as semelhanças com, neste capítulo apresentaremos a prática antropológicaterapêutica como possibilidade de produção de uma antropologia outra que escapa das dualidades Eu/Outro e do estar dentro/estar fora. Com este propósito, prosseguiremos a seguinte hipótese: em uma atividade etnográfica, ser afetado produr o desaparecimento de concepcõoes do conhecimento como verdade absoluta, lançando ao plano da experiência uma prática terapêutica no (e com o) acaso.

Para isto, nos próximos dois tonos, assumiremos uma possível interlocução entre a invenção de uma prática "etnográfica-terapêutica”, apresentada nas obras da antropóloga Jeanne Favret-Saada (FAVRET-SAADA, 1977, 2009; FAVRET-SAADA; CONTRERAS, 1981), e a "terapia filosófica" do filósofo Ludwig Wittgenstein, tendo em consideração sua obra Observações Sobre O Ramo de Ouro de Frazer, onde a teoria evolucionista do antropólogo inglês James Frazer é problematizada (WITTGENSTEIN, 2007).

Antes disto, é importante ressaltar que a expressão prática terapêutica pode ser compreendida a partir de diferentes perspectivas, tendo esta, inclusive, distintas derivadas da palavra "terapia". No entanto, dado o objetivo deste texto, aqui já apresentado, buscaremos estabelecer algumas conexões entre duas matrizes teóricas, quais sejam: a terapia filosófica de Ludwig Wittgenstein e a prática antropológica-terapêutica de Jeanne Favret-Saada.

Posto isto, procuramos semelhanças entre estas duas posturas para desenvolver nossa hipótese. Cabe destacar ainda que estas duas terapias constituem em práticas terapêuticas (filosófica e antropológica) conceituais, não sendo elas psicanalíticas, pois, antes de qualquer coisa, estas duas perspectivas, de modo descontínuo e analógico, 
expõem-se ao enfrentamento das concepções tradicionais da linguagem mediante um embate livre e polifônico. Neste caso, caberia as palavras de Almeida (2017, p. xxxv), onde “[...] ao leitor cabe apenas, e tão somente, ponderar as consequências filosóficas mais imediatas dos pressupostos que ela ou ele abraçam ou com os quais mais orientam a sua conduta" (ALMEIDA, 2017, p. xxxv). Práticas terapêuticas com as quais a "[...] filosofia deve deixar tudo como está (cf. IF \124). Ela não descobre nada, nem nada fundamenta, faz apenas "descrições". [Por isto,] a terapia gramatical não visa propor novas teses sobre metafísica ou sobre a magia, sua finalidade é apenas solucionar os problemas causados pelas ilusões gramaticais". (ALMEIDA, 2007, p. 214).

\section{Tono II - A prática antropológica-terapêutica de Jeanne Favret-Saada: être affecté}

A antropóloga francesa Jeanne Favret-Saada realizou uma pesquisa de campo entre os anos 1969 e 1972 em uma comunidade de sorcellerie (feitiçaria ou bruxaria) no Bocage, oeste da França. Nesta pesquisa, denominada como uma prática antropológica-terapêutica, a autora apresenta seus encontros com o sistema da sorcellerie como uma forma de être affecté (ser afetado). Neste tono, buscaremos problematizar esta "dimensão" do trabalho de campo na prática antropológica de Jeanne Favret-Saada como um modo de produção simultânea de si e do campo que se dá no (e com o) acaso ${ }^{8}$. Para tanto, partiremos da seguinte afirmação da autora: "J'étais précisément en train d'expérimenter ce système en y hasardant ma personne" (FAVRET-SAADA, 2009, grifos nossos) ${ }^{9}$. Realizaremos, assim, uma tradução comentada, primeiro, da expressão “j’étais présicément en train d'expérimenter ce système” e, segundo, "en y hasardant ma personne".

A dimensão antropológica aqui anunciada - être affecté - é sustentada no livro Désorceler a partir da hipótese de que “[...] l'efficacité thérapeutique, quand elle se produit, vient de ce qu'un certain travail est accompli sur l'affect non représentê"10 (Ibid., p. 145-146, grifos nossos). Em Les mots, la mort, le sorts, Favret-Saada (1977) conceberá este "afeto não representado" como algo que não se dá no plano da informação, ou seja, daquilo que o nativo lhe informa sobre si mesmo, sua cultura ou suas práticas culturais, mas de algo que captura no processo de experimentação de um être affecté. Quando ela diz "[...] j’étais précisément en train d'expérimenter ce système”, a autora está enunciando que foi capturada no processo de experimentação da sorcellerie (eu estava precisamente experimentando este sistema). Isto pode ser evidenciado, por exemplo, em Entre "prise » et reprise, quando ela narra um encontro com um nativo e ele diz "faut êt' pris pour y croire",

\footnotetext{
8 É importante destacar que, em nossa interpretação, o être affecté não designa efetivamente a pessoa Jeanne Favret-Saada, mas quem ela nomeia como elle (ela). Isto porque Jeanne estabelece uma "distância" narrativa entre ela (quem escreve) e esta elle (que esteve em campo, no caso a etnógrafa) utilizando a terceira pessoa do singular como uma invenção da experiência do campo e do texto. Mesmo tendo escrito na primeira pessoa do singular, assim ela inicia seu livro Les mots, la mort, les sorts: "Soit une ethnographe : elle a choisi [...] Elle a déjà travailler sur le terrain [...] Elle dispose d'une culture scientifique [...] Elle [...]" (FAVRET-SAADA, 1977, p. 13, grifos nossos). Como afirma Barbosa Neto (2012, p. 239) em sua análise desta obra, “'Ser afetado’ é o nome que Favret-Saada escolheu dar a essa experiência de criação que escapa à representação, uma experiência que é simultaneamente de campo e de texto, e, sobretudo, de sua sutil e delicada conexão".

${ }_{9}$ A priori, preservaremos a escrita deste trecho em francês, pois iremos explorar sua tradução como forma de apresentar nossa problemática.

${ }^{10}$ Tradução: "a eficácia terapêutica, quando ela se produz, resulta de um certo trabalho realizado sobre o afeto não representado".
} 
“pour ceux qui n'ont pas été pris, ça n'existe pas" e “ceux qui n’ont pas été pris, ils ne peuvent pas en parler" (FAVRET-SAADA, 1977, p. 28).

Nos três enunciados, o nativo afirma que para acreditar na existência do sistema da sorcellerie é preciso ser capturado (prise, assumindo-o como um modo de ser tomado, pego, preso... pelas forças mágicas que ali circulam - seja de enfeitiçamento, cura, desenfeitiçamento ou outras), pois apenas deste modo ela (a magia da sorcellerie) existirá e dela poderemos falar (reprise). Tendo isto em consideração, de acordo com Jeanne, não existe a possibilidade "[...] d'instituer quelque distance entre soi et l'indigène ou entre soi et soi" "11 (FAVRET-SAADA, 1977, p. 38). Esta impossibilidade de instituir algum distanciamento, segundo a autora, inviabiliza uma prática etnográfica baseada na "observação" e descrição dos saberes nativos (antropologia pós-estruturalista francesa) e/ou uma prática etnográfica baseada na "observação participante" (antropologia anglosaxônica). De acordo com a autora, esta última tem como base dois gêneros de comportamento, os quais são distinguidos por ela como ativo ["un travail régulier avec des informateurs rémunérés qu'ils interrogeaient et observaient" (Ibid., p. 147)] ${ }^{12}$ e passivo [“1'assistance à des événements liés à la sorcellerie (disputes, consultations de devins...) (Ibidem) $]^{13}$. Portanto,

D’une façon générale, il y avait, dans cette littérature, un glissement de sens perpétuel entre plusieurs termes qui auraient gagné à être distingués : la « vérité » venait baver sur le «réel», et celui-ci sur l' «observable» - là, on trouvait une confusion supplémentaire entre l'observable comme savoir empiriquement attestable, et l'observable comme savoir indépendant des déclarations indigènes -, puis sur le « fait », l' « acte » ou le « coin portement ». Cette nébuleuse de significations avait pour seul trait commun de s'opposer à sa symétrique: l' «erreur» bavait sur l' « imaginaire », sur l' « inobservable », sur la « croyance » et enfin sur la « parole» indigène (Ibid., p. 148).14

Nesta impossibilidade, o que vai se constituindo então é uma dimensão antropológica de être affecté, a qual, de acordo com a autora, se dá em uma prática antropológica-terapêutica onde não há, portanto, distâncias entre a etnógrafa e os nativos, sequer uma homogeneização de ambos sujeitos, constituindo assim uma unidade totalizante [quando uma “[...] ethnographe accepte d'être affecté n’implique pas qu'il s'identifie au point de vue indigène, ni qu'il profite de l'expérience du terrain pour se chatouiller l'ego" (FAVRET-SAADA, 1977, p. 158) $]^{15}$. Não sendo nenhuma destas formas que perpetuam as dualidades Eu/Outro, Observador/Observado, entre outras, poderíamos

\footnotetext{
11 Tradução: “[...] de instituir alguma distância entre si e o nativo ou entre si e si mesmo".

12 Tradução: "um trabalho regular com informantes remunerados que entrevistaram e observaram".

13 Tradução: "a assistência (ou participação) em acontecimentos relacionados com bruxaria (disputas, consultas de adivinhos...)".

${ }^{14}$ Tradução: "De modo geral, nesta literatura, houve uma perpétua mudança de sentido entre vários termos que teriam se beneficiado com a distinção: a 'verdade' estava escorrendo sobre o 'real', e este último sobre o 'observável' (aqui havia uma confusão entre observável como conhecimento empiricamente verificável, e o observável como conhecimento independente das declarações nativas) e depois sobre o 'fato', o 'ato' ou o 'comportamento'. Essa nebulosa de significações tinha apenas por traço comum opor-se a seu simétrico: o 'erro' escorria no 'imaginário', no 'inobservável', na 'crença' e finalmente no 'discurso' nativo".

15 Tradução: "[...] quando um etnógrafo aceita ser afetado não implica que ele se identifica com o ponto de vista do nativo, nem que ele aproveita da experiência de campo para fazer cócegas no ego". No texto, optamos por assumir o feminino por se tratar de "uma etnógrafa", mulher.
} 
dizer que há tão somente a invenção de uma elle (ou de um il-ele), isto é, uma terceira pessoa do singular, uma "personagem" inventada no processo de experimentação para fazer existir a si mesma enquanto expressão da magia de être affecté e do próprio texto etnográfico. Com efeito, essa personagem carrega como modo de expressão de si "alguma coisa" que prise et reprise no campo (l'affect non représenté).

Favret-Saada apresenta uma situação onde esta "alguma coisa" (l'affect non représenté) se dá quando ela é capturada pelo sistema da sorcellerie:

L'une des situations que je vivais sur le terrain était pratiquement inracontable : elle était si complexe qu'elle défiait la remémoration et, de toute façon, elle m'affectait trop. Il s'agit des séances de désorcèlement auxquelles j'assistais soit comme ensorcelée (ma vie personnelle était passée au crible et j'étais sommée de la modifier), soit comme témoin aussi bien des clients que de la thérapeute (j'étais constamment sommée d'intervenir à brûle-pourpoint) [...]. Une fois que j'ai accepté d'occuper la place qui m'était assignée dans les séances, je n'ai presque plus jamais pris de notes : tout allait trop vite, je laissais se faire les situations sans me poser de questions et, de la première séance à la dernière, je n'ai quasiment rien compris de ce qui se passait. (FAVRET-SAADA, 2009, p. 155). ${ }^{16}$

A expressão J'étais précisément en train d'expérimenter ce système significa, assim, “[...] prenne le risque de voir s'évanouir son projet de connaissance" (Ibid., p. 158-159, grifos nossos $)^{17}$. Desse modo, encontramo-nos em nosso segundo grifo da citação a qual partimos, qual seja: ... en y hasardant ma personne. Enquanto este trecho poderia ser traduzido como "expondo-me a mim mesma" 18 insistimos um pouco mais na palavra hasardant. Primeiro, porque "expondo-me a mim mesma" poderia ser traduzida como exposant à moimême, m'exposant, ou outras maneiras da língua francesa; segundo, porque hasardant deriva do verbo transitivo hasarder. No primeiro caso, a exposição de si mesma pode não significar que uma imprevisibilidade será engendrada no processo a qual se é exposto; no segundo caso, quando guardamos o verbo hasarder, temos em conta que o mesmo é composto pelo substantivo hasard, que significa chance, sorte, possibilidade, entre outras, também acaso (prenne le risque $)^{19}$. Isto posto, en y hasardant ma personne carrega consigo nossa perspectiva de interpretação do être affecté como uma dimensão que se dá no (e com o) acaso (correr o risco de ver seu projeto de conhecimento se desvanecer).

Assim, podemos sintetizar este processo da seguinte maneira: être affecté é uma dimensão antropológica que inventa uma personagem da experimentação (elle ou it) como expressão da magia dos processos prise et reprise. Estes, determinam a existência da magia de être affecté (prise) e a possibilidade de sobre ele falar (reprise). Toda esta dimensão se

\footnotetext{
16 Tradução: "Uma das situações que eu estava vivendo em campo era quase inenarrável: era tão complexa que desafiava a rememoração e, de qualquer forma, afetava-me demais. Estas sessões de desenfeitiçamento que participei, seja como enfeitiçada (minha vida pessoal estava passando por um crivo e fui instada a modifica-la) seja como testemunha dos clientes, mas também da terapeuta (era constantemente instada a intervir instantaneamente) [...]. Uma vez que eu aceitei ocupar o lugar designado para mim nas sessões, quase nunca mais tomei notas: tudo se passava muito rápido, deixei as situações acontecerem sem fazer perguntas $e$, da primeira sessão até a última, não entendi quase nada do que estava acontecendo."

${ }_{17}$ Tradução: “[...] correr o risco de ver seu projeto de conhecimento se desvanecer".

18 A interpretação de "y hasardant ma personne" como uma forma de "exposição de si mesma" é feita, por exemplo, na tradução para o português do capítulo Être affecté, realizada por Paula Siqueira. Vide: (FAVRET-SAADA, 2005).

${ }^{19}$ Para Favret-Saada (1977, p. 234), não existe uma forma de ser capturado pela sorcellerie sem que se corra nenhum risco, neste caso o de ser enfeitiçado. Em suas palavras, "il était clair pour moi que ne pouvais à la fois admettre d'y être « prise » et ne courir aucun risque" - tradução: "Estava claro para mim que eu não podia admitir que estava "presa" nela [no sistema da sorcellerie] e não correr nenhum risco".
} 
desdobra no (e com o) acaso - basard -; lugar onde, na antropologia, é-se bombardeado por intensidades de "alguma coisa" que acontece no campo, e da qual elle/il (personagem) é produto de uma constante comunicação entre estas "algumas coisas" que se situam no afeto não representado. Esta comunicação é chamada por Favret-Saada $(1977,2009)$ de comunicação involuntária.

Estas duas últimas linhas nos deixa uma questão ainda não apresentada neste tono, qual seja: de que maneira esta comunicação se estabelece, dado que nela são partilhados afetos não representados? Para problematizar tal questão, evoquemos novamente um dos enunciados que sustentam o Entre prise et reprise de Favret-Saada (1977, p. 28, grifos nossos): “ceux qui n'ont pas été pris, ils ne peuvent pas en parler".

Dado que être affecté diz respeito a uma dimensão antropológica que implica experimentar alguma coisa que acontece no campo - designada aqui como uma experiência no (e com o) hasard-, quer dizer que ser bombardeado por intensidades específicas significa, então, ocupar/habitar um outro lugar. Retomando a situação de captura de Favret-Saada, apresentada na página anterior, temos esta evidência da seguinte maneira: "Une fois que j'ai accepté d'occuper la place qui m'était assignée dans les séances [...]”. Isto nos conduz a questionamentos como: que lugar é este que ela é designada a ocupar? De forma direta, poderíamos dizer que este lugar é o mesmo que possibilita a experimentação no (e com o) acaso do sistema da sorcellerie, o que constitui a dimensão do être affecté. Por isto, em distinção ao que Favret-Saada (1977, p. 24) caracteriza como place ordinaire (lugar ordinário) ${ }^{20}$ ao se referir à etnografia, denominemo-lo de lugar afecção.

A autora apresenta este lugar ordinário em sua etnografia da seguinte maneira:

On voit qu'il ne s'agit pas exactement d'une situation classique d'échange d'information, dans laquelle l'ethnographe pourrait espérer se faire communiquer un savoir innocent sur les croyances et les pratiques de sorcellerie. Car qui parvient à les connaitre acquiert un pouvoir et subit les effets de ce pouvoir : plus on sait, plus on est menaçant et plus on est menacé magiquement. Tant que j'ai occupé la place ordinaire de l'ethnographe, celle qui prétend désirer savoir pour savoir, mes interlocuteurs s'intéressaient moins à me communiquer leur savoir qu'à mesurer le mien, à devenir l'usage nécessairement magique que j'entendais en faire, à développer leur « force » au détriment de la mienne (Ibid., p. 24, grifos nossos) $)^{21}$.

Cabe ressaltar, assim, que além de ser ele um lugar onde se pretende "saber para saber", ele diz respeito a uma prática que pretende uma "neutralidade" e que, nas palavras da Favret-Saada, não é possível. Isto porque, como ela mesma afirma, plus on sait, plus on est menaçant et plus on est menacé magiquement. Se o campo etnográfico de Jeanne Favret-Saada se apresenta não na ocupação de um lugar onde se informa um dado conhecimento da magia,

\footnotetext{
${ }^{20}$ Geralmente traduzido, neste contexto, como "lugar comum". Porém, dada a severa crítica que a autora atribui à etnografia, evocando fortemente a necessidade de praticar uma outra etnografia ["quand la parole, c'est la guerre totale, il [l'ethnographe] fau résoudre à pratiquer une autre ethnographie" - Tradução: "Quando a palavra é a guerra total, ele [o etnógrafo] teve que resolver praticar outra etnografia"] Ibid., p. 24).

${ }^{21}$ Tradução: "Podemos ver que esta não é exatamente uma situação clássica de troca de informações, na qual o etnógrafo poderia esperar ter um vislumbre inocente das crenças e práticas de bruxaria. Para quem as conhece, adquire poder e sofre os efeitos desse poder: quanto mais se sabe, mais se está magicamente ameaçado. Enquanto eu ocupava o lugar comum do etnógrafo, aquele que afirma querer saberpara saber, meus interlocutores estavam menos interessados em me comunicar seu conhecimento do que em medir o meu, em se tornar o uso necessariamente mágico que eu pretendia fazer dele, em desenvolver sua "força" em detrimento da minha".
} 
mas como uma possibilidade mágica de ser prise, capturado por um sistema onde os afetos não representados possuem uma dimensão de constituição no (e com o) hasard, é porque, como realça a autora, foi ocupado um lugar que a ela foi designado. É este que denominamos de lugar afecção.

Nele, não importa a suposição de uma distância entre o etnógrafo e o nativo [“" [...] c'est bien parce qu'on n'est pas à la place de l'autre qu'on tente de se représenter ou d'imaginer ce que ce serait d'y être, quels sentiments, perceptions et pensées on aurait alors" (FAVRET-SAADA, 2009, p. 156)22, sequer uma "comunicação afetiva" onde se busca a compreensão e identificação de seus afetos ["cette conception est muette sur le mécanisme de l'identification, mais elle insiste sur son résultat, le fait qu'elle permette de connaitre les affects d'autrui" (Ibid., p. 156)] $]^{23}$. Esta é a crítica e oposição levantada por Favret-Saada (2009) às duas acepções da ideia de "empatia" na etnografia, pois, segundo a autora, no primeiro caso, ela havia aceitado ocupar um lugar designado nas seções de sorcellerie “[...] j’étais justement à la place de l'indigène, agitée par les sentiments, perceptions et pensées de ce qui occupe une place dans le système sorcellaire" (Ibid., p. 156) ${ }^{24}$, no segundo, ela considera que ocupar este lugar não lhe dá poder sobre os afetos do outro os nativos - [“[...] occuper telle place dans le système sorcellaire ne me renseigne en rien sur les affects de l'autre [...]" (Ibid., p. 156)] $]^{25}$. Ao contrário disto, poderíamos dizer que ocupar um lugar afecção trata-se de experimentar a possibilidade de se lançar (a si mesmo - en y hasardant ma personne) ao hasard, isto é, à eventualidade de uma comunicação involuntária dos afetos não representados. Sobre este lugar, citemos Favret-Saada (2009, p. 156, grifos nossos):

[...] quand on est dans une telle place, on est bombardé d'intensités spécifiques (appelons-les des affects), qui ne se signifient généralement pas. Cette place et les intensités qui lui sont attachées ont donc à être expérimentées: c'est la seule façon de les approcher [...] occuper telle place m'affecte, moi, c'est-à-dire mobilise ou modifie mon propre stock. d'images, sans pour autant m'instruire sur celui de mes partenaires. ${ }^{26}$

A comunicação involuntária, mencionada pela autora, por ser desprovida de intencionalidade mas munida de afetos não representados, diz respeito à ocupação de um lugar da experimentação que, em seu trabalho, significa "entrar no jogo" ${ }^{\text {"27 }}$ da sorcellerie “[...] il était temps que je prenne moi-même la parole” (FAVRET-SAADA, 1977, p. 31) ${ }^{28}$. Além disto, significa se engendrar em um enfeitiçamento de si mesmo. Quando isto ocorre,

\footnotetext{
22 Tradução: “[...] é porque não estamos no lugar do outro que tentamos representar e nos imaginar como seria estar lá, que sentimentos, percepções e pensamentos teríamos então".

${ }^{23}$ Tradução: "essa concepção é omissa quanto ao mecanismo de identificação, mas ela insiste em seu resultado, no fato de que permite conhecer os afetos do outro".

${ }^{24}$ Tradução: “[...] eu estava justamente no lugar do nativo, agitada por seus sentimentos, percepções e pensamentos de quem ocupa um lugar no sistema da feitiçaria".

${ }^{25}$ Tradução: “[...] ocupar tal lugar no sistema da feitiçaria não me diz nada sobre os afetos do outro [...]”.

${ }^{26}$ Tradução: “[...] quando estamos em um tal lugar, somos bombardeado com intensidades específicas (chamemo-las de efeitos), que geralmente não são significadas. Este lugar e as intensidades a ele ligadas têm que ser experimentadas: é a única maneira de se aproximar deles [...]; ocupar tal lugar me afeta, ou seja, mobiliza ou modifica meu próprio estoque de imagens, sem me instruir sobre as dos meus parceiros".

${ }^{27}$ Para Favret-Saada (1977), "entra no jogo" significa aceitar ocupar o lugar designado dentro do sistema da sorcellerie, tanto no que diz respeito à linguagem verbal (maneiras de enunciar algo dentro do sistema) quanto no que implica uma comunicação não-verbal, isto é, os afetos não representados (como o envolvimento afetivo da de um personagem com outro, onde o projeto de conhecimento entra em uma aventura de desvanecimento.

${ }^{28}$ Tradução: "[...] era tempo de eu mesma falar".
} 
nosso estoque de imagens é mobilizado, momento em que a experiência ganha dimensão terapêutica. Em outras palavras, é na mobilização de si mesmo, na invenção de uma personagem (elle; i⿱ $)$ que suporta as intensidades específicas que nos bombardeiam que uma terapia no (e com o) acaso é produzida como expressão de uma experimentação. Esta comunicação, que pode ser verbal ou não verbal, é exemplificada pela autora da seguinte maneira:

Quand elle est verbale, il se passe à peu près ceci : quelque chose me pousse à parler (disons, de l'affect non représenté), mais je ne sais pas quoi, pas plus que je ne sais pourquoi cela me pousse à dire justement cela. Par exemple, je dis à un paysan, en écho à quelque chose qu'il m’a dit: «Justement, j’ai rêvé que ... », et je serais bien en peine de commenter ce « justement». Ou encore, mon interlocuteur remarque, sans établir de lien : «L'autre jour, Untel vous a dit que ... Aujourd'hui, vous avez ces boutons sur la figure ... ». Ce qui se dit là, implicitement, c'est le constat de ce que je suis affectée : dans le premier cas, je fais moi-même ce constat; dans le second, c'est l'autre qui le fait. Quand cette communication n'est pas verbale, qu'est-ce donc qui est communiqué et comment ? Il s'agit bien de la communication immédiate qu'évoque le terme d'Einfüblung. Pourtant, ce qui m'est communiqué, c'est seulement l'intensité dont l'autre est affecté (le premier Freud parlerait d'un « quantum d'affect ", ou d'une charge énergétique). Les images qui, pour lui et pour lui seul, sont associées à cette intensité échappent à cette communication. De mon côté, j’encaisse cette charge énergétique à ma façon, personnelle : j’ai, mettons, un trouble provisoire de la perception, une quasi hallucination, ou une modification des dimensions; ou encore, je suis submergée par un sentiment de panique ou d'angoisse massive. (FAVRET-SAADA, 2009, p. 157-158). ${ }^{29}$

Por isto, em Favret-Saada (2009, p. 159-161), um processo como este (de être affecté) abre quatro movimentos distintos em sua outra prática etnográfica, quais sejam: 1) em vez de maquiar episódios da experiência de campo como expressão de uma comunicação voluntária e intencional, ela escolhe dar uma estatuto epistemológico à sua etnografia; 2) ela supõe que o pesquisador vive em uma estado schize (esquizo), e por isto ele mesmo, seus estoques de imagens pessoais, é modificado pela experiência de campo; 3) a análise (reprise) vem apenas a posteriori, pois enquanto somos afetados, somos enfeitiçados e ameaçados constantemente pela não representatividade da magia; 4) o material produzido em campo possui potencial e densidade bastante para romper com certezas científicas consideradas estáveis na academia. Tais movimentos, em nossa interpretação, sustentamse no (e com o) hasard, em uma forma de pensar algo que acontece no campo "[...] comme

\footnotetext{
${ }^{29}$ Tradução: "Quando ela é verbal, é algo assim: algo me impulsa a falar (digamos, do afeto não representado), mas eu não sei o quê, assim como não sei porque me impulsiona para dizer exatamente isso. Por exemplo, digo a um camponês, ecoando algo que ele tinha me dito: "Justamente, eu sonhei que ..." e eu não teria como comentar este "justamente". Ou então meu interlocutor comenta, sem estabelecer uma ligação: 'Outro dia, fulano lhe disse que... Hoje, você está com essas espinhas no rosto...'. O que é dito aí, implicitamente, é a afirmação de que sou afetada. No primeiro caso, eu mesma faço essa constatação, no segundo, é o outro quem a faz. Quando esta comunicação não é verbal, o que é comunicado e como? Esta é a comunicação imediata que o termo Einfüblung evoca. Entretanto, o que me é comunicado é apenas a intensidade com que o outro é afetado (o primeiro Freud falaria de um 'quantum de afeto', ou de uma carga energética). As imagens que para ele, e somente para ele, estão associadas a esta intensidade escapam desta comunicação. De minha parte, trato essa carga de energia da minha forma, pessoal: tenho, digamos, um distúrbio perceptivo temporário, uma quase alucinação, ou uma mudança nas dimensões; ou ainda estou submersa por um sentimento de pânico ou angústia maciça”.
} 
une force anonyme, comme un 'ça' venu on ne sait d'où [...]" (FAVRET-SAADA, 1977, p. 236$)^{30}$.

\section{Tono III - Entrar no Sprachspiel e distorcer as imagens: uma virada antropológica de Ludwig Wittgenstein}

Wir sind, wenn wir philosophieren, wie wilde, primitive Menschen, die Ausdrucksweise zivilisierter Menschen hören, sie mißdeuten und nun die seltsamsten Schlüsse aus ihrer Deutung ziehen (WITTGENSTEIN, 2017, \$194)31.

Como já anunciado, a citação acima apresentada como início deste tono é um aforisma do livro Investigações Filosóficas do filósofo austríaco Ludwig Wittgenstein (18891951). Nele, Wittgenstein (2017) busca nos fazer refletir sobre as formas de praticar a filosofia na tradição clássica, ou seja, que exprime uma visão de mundo marcada pela concepção clássica da linguagem de Santo Agostinho e o essencialismo platônico. Estas, possuem uma finalidade filosófica de esclarecimento lógico dos pensamentos através do uso da explicação como ferramenta para a construção de conhecimento cientificamente legítimo.

Os problemas da natureza da proposição e da linguagem que envolveram a primeira obra publicada por Wittgenstein - o Tractatus Logico-Philosophicus - tiveram como ponto de partida os trabalhos de Bertrand Russell e Gottlob Frege. Tais problemas procuravam estabelecer uma ligação entre a estrutura lógica do mundo e a estrutura lógica da linguagem, ligação esta que, à luz do Tractatus Logico-Philosophicus (1994), possibilita que, através da linguagem, possamos falar sobre o mundo. A proposta se centralizava em que proposições lógicas podiam representar o mundo. Com a publicação desta obra, o filosofo acreditava ter solucionado todos os problemas relevantes para a filosofia. Por isto, ele diz: "[...] Dagegen scheint mir die Wabrheit der bier mitgeteilten Gedanken unantastbar und definitiv" (WITTGENSTEIN, 1994, p. 12) ${ }^{32}$.

No entanto, em seu livro Investigações Filosóficas (WITTGENSTEIN, 2017), onde são reunidos um conjunto de aforismas, Wittgenstein, ao problematizar a concepção de linguagem de Santo Agostinho, abre margem para novas reflexões através do que ele denomina de terapia filosófica. Em suas palavras,

[...] In diesen Worten erhalten wir, so scheint es mir, ein bestimmtes Bild von dem Wesen der menschlichen Sprache. Nämlich dieses: Die Wörter der Sprache benennen Gegenstände - Sätze sind Verbindungen von solchen Benennungen. In diesem Bild von der Sprache finden wir die Wurzeln der Idee: Jedes Wort hat eine Bedeutung.

\footnotetext{
30 Tradução: “como uma força anônima, como um ‘isso' que não sabemos de onde vem”.

31 Tradução: 'Quando filosofamos somos como selvagens, pessoas primitivas que ouvem o modo de expressão dos civilizados, o interpretam mal, e agora tiram as conclusões mais bizarras da sua interpretação'. (WITTGENSTEIN, 2017, $\$ 194)$.

32 Tradução: "a verdade dos pensamentos aqui comunicados parece-me intocável e definitiva. Portanto, é minha opinião que, no essencial, resolvi de vez os problemas".
} 
Diese Bedeutung ist dem Wort zugeordnet. Sie ist der Gegenstand, für welchen das Wort steht (WITTGENSTEIN, 2017, \$1) 33 .

"Ein bestimmtes Bild von dem Wesen der menschlichen Sprache" significa uma visão da linguagem que é predominante na tradição filosófica ocidental, a teoria referencial do significado, com a qual uma palavra possui um único significado se a ela corresponde um objeto.

Vale a pena notar que, após a publicação do "Tractatus", ele abandona a filosofia, pois, ao final das contas, ele acreditava ter resolvido os problemas que eram objeto da filosofia com relação à linguagem. No entanto, entre 1930 e 1931, após seu primeiro contato com "The Golden Bough", publicado pelo antropólogo evolucionista de gabinete Sir James George Frazer (1854-1941), Wittgenstein começa a produzir diferentes observações sobre ele. Estas, foram organizadas e publicadas postumamente por Elizabeth Anscombe ${ }^{34}$, sob o título: Bemerkungen über Frazers Golden Bough e traduzido para o português como Observações sobre o Ramo Dourado de Fražer.

Estas observações podem ser compreendidas como o empreendimento de uma nova visão da linguagem e o início de algumas das ideias que caracterizarão sua visão posterior. Wittgenstein encontra no "The Golden Bough" um suporte para uma nova forma de ver e praticar a filosofia, começando a entender que a tarefa da filosofia é a elucidação das confusões $^{35}$ linguísticas geradas pelo desejo de explicação cientificista que atravessa toda a produção intelectual ocidental. A crítica de Wittgenstein (2007) a Frazer não é no domínio da lógica, mas sim ao seu cientificismo, a saber, quando o antropólogo interpreta certos comportamentos dos nativos tendo como base a cultua inglesa do seu tempo.

Como primeiro passo, Wittgenstein começa rejeitando a noção de Frazer de que as práticas mágico-religiosas dos povos indígenas estudados por ele, se baseiam em um erro básico de raciocínio dos participantes, pois, em suas palavras, "Frazer kann sich keinen Priester vorstellen, der nicht im Grunde ein englischer Parson unserer Zeit ist, mit seiner ganzen Dummbeit und Flaubeit"36. Essa "estupidez" e "debilidade" que Wittgenstein vê em Frazer tem a ver com o fato de assumir uma atitude dogmática e cientificista ao se aproximar das práticas destes povos, ou seja, a de encarar os arquivos por ele manipulados para organizar juízos de valor, com base nas suas crenças cientificistas, que serviriam como padrão de correção das ações performadas pelos praticantes dos rituais. Wittgenstein (2007, p. 193), assim, nos oferece um exemplo crítico da seguinte maneira:

Frazer sagt, es sei sehr schwer, den Irrtum in der Magie zu entdecken — und darum halte sie sich so lange — weil z.B. eine Beschwörung, die Regen herbeiführen soll, früher oder später gewiss als wirksam erscheint. Aber dann ist es eben merkwürdig,

\footnotetext{
33 Tradução: "Nessas palavras conservamos, assim me parece, uma determinada imagem da essência da linguagem humana. A saber, esta: as palavras da linguagem denominam objetos - proposições são combinações de tais denominações. Nessa imagem da linguagem encontramos as raízes da ideia: toda palavra tem um significado. Este significado é correlacionado à palavra. Ele é o objeto que a palavra substitui”. (WITTGENSTEIN, 2017, \$1).

${ }^{34}$ Uma das executoras literárias, tradutora e comentarista de Wittgenstein.

35 "As confusões que nos ocupam surgem, por assim dizer, quando a linguagem roda no vazio, não quando trabalha" (WITTGENSTEIN, 2017, \$132).

36 Tradução: "Frazer não consegue pensar em nenhum sacerdote que não seja, fundamentalmente, um pároco inglês do nosso tempo, com toda a sua estupidez e debilidade" (WITTGENSTEIN, 2007, p. 196).
} 
dass die Menschen nicht früher darauf kommen, dass es ohnehin früher oder später regnet ${ }^{37}$.

"Frazer sagt, es sei sehr schwer, den Irrtum in der Magie zu entdecken" não apenas pelo fato de acreditar que sua explicação é convincente, no âmbito da lógica própria do campo cientifico, acerca do mecanismo da relação de causa/efeito entre a cerimônia e o fazer chove, mas também pelo fato dele argumentar que todo "comportamento mágico" é utilizado por falta de conhecimento teórico adequado. Isto pode ser observado nos esforços de Frazer para relatar de forma detalhada em seu livro como os "primitivos" recorriam à "magia" quando suas capacidades de lidar realisticamente com as situações se esgotavam. A magia seria, desse modo, uma espécie de "realidade substituta".

O aforismo acima citado, extraídos das observações feitas por Wittgenstein, remetenos à atitude antropológica de Frazer. Esta atitude pode ser caracterizada como um movimento provocado pelos efeitos do olhar para o outro com os parâmetros da própria cultura. Isto pode ser notado, por exemplo, quando ele afirma que: "dann ist es eben merkwürdig, dass die Menschen nicht früher darauf kommen, dass es obnehin früher oder später regnet". Em outras palavras, para Frazer a dança da chuva é entendida como uma estupidez, pois "o antropólogo supõe que os selvagens estejam pensando em termos de causas e efeitos, utilizando a dança da chuva com o objetivo de provocar uma mudança meteorológica" (ALMEIDA, 2007, p. 216). No entanto, Wittgenstein reiterará que se trata de uma prática legítima nesta forma de vida e o erro do olhar de Frazer estar em projetar neles algo que era nosso, criando confusões.

Wittgenstein (2007), desse modo, entende que os rituais expressam condições de sentido e orientam as pessoas para agir de um modo ou de outro no contexto de uma prática social. Nesse sentido, a terapia filosófica proposta por ele possui uma ação (como algo que se ocupa apenas em dizer) de descrição de como as formas de vida, suas crenças e expressões da linguagem, organizam a experiência de uma determinada maneira, interrelacionado seus objetos.

É claro que a dança da chuva é uma estupidez de acordo com a visão deste antropólogo do começo do século XX, pois esta prática, organizada pelos indígenas, não comporta, e nem satisfaz, os critérios da racionalidade científica, bem como as finalidades de uma dança na Europa “civilizada”. Uma vez que, como salienta Almeida (2007, p. 217):

Não há uma causa que origina o comportamento dos selvagens. Tudo ocorre dentro da sua própria forma de vida: todos concordamos e entendemos imediatamente, sem apelo a qualquer tipo de segunda reflexão, que tudo aquilo é temível. O fato de estarmos numa forma de vida nos faz ver as coisas como horripilantes ou como triviais, segundo o caso, e tudo isso faz parte da vida, simplesmente mudança da estação ou do clima. Desse ponto de vista, constitui um erro buscar explicações adicionais. [...] O amor, como a magia, a dança da chuva, um aperto de mãos, um meneio de saudação, não pode ser considerado como verdadeiro nem falso - tratamse de expressões.

\footnotetext{
${ }^{37}$ Tradução: "Frazer diz que é muito difícil descobrir o erro na magia - e por isso ela dura tanto - porque, por exemplo, uma conjuração para trazer chuva, deve, mais cedo ou mais tarde, certamente aparecer como eficaz. Mas então é muito estranho que as pessoas não notem mais cedo que, de todo modo, mais cedo ou mais tarde chove" (WITTGENSTEIN, 2007, p. 193).
} 
Este posicionamento, como muitos outros, localizados no percurso da obra do antropólogo inglês, são tão etnocêntricos quanto evolucionistas, cientificistas, dogmatizantes e universalizantes, pois, por um lado, seus critérios de racionalidade, da finalidade de uma dança, ou de cientificidade e de meteorologia, não são satisfeitos por essa prática, e, por outro lado, suas apreciações induzem pensar que os indígenas "dançam" e "saltam" para "fazer chover" e, os europeus, mais "civilizados", não, pois, ao "evoluírem" a um estágio intelectual entendido como "superior", deixaram de fazê-lo.

Para Wittgenstein, a fonte de estranheza do relato de Frazer está situada no fato de que as práticas socioculturais destes povos são definidas como errôneas ou estúpidas. Além disto, o fato implícito de que um praticante destes rituais teria que ser estúpido para continuar os praticando, faz com que Frazer trate estas práticas não apenas como uma magia metafísica, mas também com desdém. Por outro lado, Wittgenstein (2007, p. 195) defenderá que: "Der selbe Wilde, der, anscheinend um seinen Feind zu töten, dessen Bild durchsticht, baut seine Hütte aus Holz, wirklich und schnitz̨t seinen Pfeil kunstgerecht und nicht in effigie"38.

O filósofo nos ajudará a exprimir novas formas de fazer e pensar a filosofia. De modo terapêutico, ele questionará em cada nova observação o modelo explicativo de Frazer com o qual o antropólogo sobrepõe os parâmetros da racionalidade cientificista de forma dogmática para ler, criticar e julgar os modos com os quais são praticados os rituais em certas formas de vida, lançando um modelo hipotético, onde caberia uma descrição. Tal modo explicativo está vinculado ao projeto interpretativo dos fenômenos do mundo da filosofia clássica - tanto no campo da ciências empíricas quanto dedutivas - que tem como propósito encontrar elementos "novos" (conexões, causas, mecanismos, leis, processos, entidades "ocultas" etc.) que, supostamente, mediante um processo eloquentemente organizado em causas e efeitos, permite verificar ou refutar uma hipóteses com base na consistência e inconsistência de conjuntos e proposições, recorrendo-se à experimentação e à Lógica clássica.

"Nur beschreiben kann man hier und sagen: so ist das menschliche Leben" ${ }^{39}$ pode ser pensado, junto a Favret-Saada (1977, p. 28), como “[...] j'étais précisément en train d'expérimenter ce système", ou seja, como uma maneira de deixar-se ser capturado pelas práticas em um processo de experimentação que não predispõe uma ação dogmática do pensamento. Usando as palavras de Wittgenstein (2017), o pesquisador ou o terapeuta se modifica em um trabalho de campo ao se pôr ao hasard dos rituais. Este processo não se dá como parte de uma verificação das teorias sobre o mundo e seus acontecimentos ou expressões, mas ao se hasardant (- a si mesmo - "entrando no jogo") junto aos elementos constitutivos da linguagem. De acordo com Wittgenstein (2017), apenas desta maneira poderíamos descrever como as práticas ou rituais das formas de vida funcionam, isto porque, tanto os rituais quanto as práticas de magia desses povos, acabaram sendo subordinados a discursos colonialistas. Organizados de forma poética por Frazer, são atitudes em relação ao mundo, são formas de viver e experienciar o mundo orientadas por regras, sentidos e significados de todas as ações a elas involucradas.

\footnotetext{
38 Tradução: O próprio selvagem, que aparenta matar seu inimigo, cuja imagem perfura, constrói realmente a sua cabana de madeira e entalha artisticamente a sua flecha, e nunca em efígie.

39 Tradução: "Aqui só se pode descrever e dizer: assim é a vida humana".
} 
Einer Regel folgen, das ist analog dem: einen Befehl befolgen. Man wird dazu abgerichtet und man reagiert auf ihn in bestimmter Weise. Aber wie, wenn nun der Eine so, der Andere anders auf Befehl und Abrichtung reagiert? Wer hat dann Recht? Denke, du kämst als Forscher in ein unbekanntes Land mit einer dir gänzlich fremden Sprache. Unter welchen Umständen würdest du sagen, daß die Leute dort Befehle geben, Befehle verstehen, befolgen, sich gegen Befehle auflehnen, usw.?

Die gemeinsame menschliche Handlungsweise ist das Bezugssystem, mittels dessen wir uns eine fremde Sprache deuten (WITTGENSTEIN, 2017, \$206) ${ }^{40}$.

Compreender o "Bezugssystem" denota um deslocamento significativo no modus operandis da filosofia praticada por Wittgenstein. Esta, contrapõe-se aos modos hermenêutico-verificacionistas e dogmáticos da antropologia praticada por Frazer, colocando-nos diante do que denominamos de processos de pesquisa antropológicos (auto)terapêuticos. Estes processos estão interessados nas regularidades que se manifestam na linguagem ao percorrer os usos das palavras se valendo de analógicas remissivas ${ }^{41}$ como ferramenta persuasiva para a dissolução de confusões filosóficas. Como estrangeiros, significa entrar no que Wittgenstein (2017) denomina por 'Sprachspiele "expressando um "sair de si em abertura para se tornar outro". Desse modo, o pesquisador é um recém-chegado em territórios desconhecidos engajado na participação de práticas socioculturais ou ritualísticas que se desenvolvem no território do trabalho de campo, onde a língua falada pode ou não ser compartilhada.

'Nur beschreiben kann man hier und sagen: so ist das menschliche Leben ${ }^{\star 3}$ é o convite feito por Wittgenstein a seus leitores para afirmar que: "Frazer ist viel mehr savage, als die meisten seiner savages, denn diese werden nicht so weit vom Verständnis einer geistigen Angelegenheit entfernt sein, wie ein Engländer des 20sten Jahrhunderts. Seine Erklärungen der primitiven Gebräuche sind viel roher, als der Sinn dieser Gebräuche selbst" ${ }^{44}$.

"Frazer ist viel mehr savage als die meisten seiner savages" 45 , para Wittgenstein (2007), porque ele emprega métodos e argumentos cientificistas para construir uma narrativa antropológica sobre os rituais e crenças indígenas. Estes métodos e argumentos utilizados para interpretar a realidade destes povos têm como base as teorias de seu tempo, fazendo com que sua interpretação assumisse as práticas culturais como práticas mágicas e

\footnotetext{
40 Tradução: "Seguir uma regra é análogo a: obedecer a uma ordem. Treina-se para isso, e se reage a ela de determinado modo. Mas o que acontece se, à ordem e ao treinamento, um reage assim, e o outro de outra maneira? Quem está certo, então? Imagine que você chegasse, como pesquisador, numa terra desconhecida com uma linguagem totalmente estranha para você. Em que circunstâncias você diria que as pessoas ali dão ordens, as compreendem, obedecem, se rebelam contra elas, e assim por diante? O modo de agir humano comum é o sistema de referência pelo qual interpretamos uma linguagem estranha” (WITTGENSTEIN, 2017, \$206).

41 A prática terapêutica do pensamento conceitual, ao modo em que Wittgenstein (2017) a compreende, age analogicamente. Isto quer dizer que, o pesquisador/terapeuta é remetido a diferentes campos de significação que envolvem o seu problema de pesquisa através de ligações analógicas entre diferentes jogos de linguagem. Desse modo, ele vai mostrando de forma panorâmica sua constatação de partida, ligando diferentes pontos de vista e estabelecendo semelhanças de família entre esses jogos de linguagem e seu ponto de partida, o que lhe permitirá dissolver confusões conceituais. Consideramos que esse processo remissivo de uma analogia a outra parte da concepção de que "todas essas práticas certamente vê-se algo que se assemelha com a associação de ideias e lhe é aparentado. Poder-se-ia falar de uma associação de práticas" (WITTGENSTEIN, 2007, p. 206).

42 Tradução: Jogo de linguagem.

43 Tradução: ‘Aqui só se pode descrever e dizer: assim é a vida humana’. (WITTGENSTEIN, 2007, p. 194).

${ }^{44}$ Tradução: "Frazer é muito mais savage (selvagem) que a maioria dos seus savages (selvagens), pois estes não estariam tão longe da compreensão de uma questão mental remota quanto um inglês do século XX. Suas explicações das práticas primitivas são muito mais toscas que o próprio sentido dessas práticas". (WITTGENSTEIN, 2007, p. 200).

45 Tradução: "Frazer é muito mais savage (selvagem) que a maioria dos seus savages (selvagens) [...]" (WITTGENSTEIN, 2007, p. 200).
} 
religiosas. As explicações de Frazer "der primitiven Gebräuche sind viel roher" se justificam pelo seu abuso das possibilidades do discurso científico, onde o antropólogo opera de forma dogmática. Por tentar elaborar uma correspondência entre a visão científica de mundo em que ele se encontrava e o mundo dos indígenas - elaborando julgamentos dos rituais e crenças destes povos se valendo de critérios cientificamente pré-estabelecidos para afirmar que aquelas formas de vida eram versões rudimentares da ciência - poderíamos dizer, junto a Wittgenstein (2007), que a investigação de Frazer se ocupava em representar o modo pelo qual outras culturas produziam seus conhecimentos tendo em conta os critérios pelos quais a cultura do próprio Frazer produzia conhecimento.

Ao assumirmos a perspectiva crítica de Wittgenstein, podemos dizer que o problema das explicações antropológicas de Frazer não estão necessariamente nos valores da verdade ou falsidade de suas afirmações, mas apenas no fato delas serem explicações construídas a partir de um padrão de correção da gramática operacionalizada pela ciência europeia. Com isto, poderíamos dizer que Frazer não compreende as outras formas de produzir o mundo devido sua incapacidade de "entrar nos Sprachspiel", de se deixar enfeitiçar pelas magias e rituais deste povos, isto, de être affecté. Além disto, por ocupar um lugar ordinário da etnografia que busca produzir uma interpretação coerente com as práticas analisadas, respondendo, então, aos critérios da sua forma de vida. Nunca os tendo visitado, Frazer termina sendo injusto com estes povos por não viverem como o seu povo, por suas formas de vida não serem reflexos de si mesmo. Por isto, o antropólogo ignora que: "[...] die gemeinsame menschliche Handlungsweise ist das Bezugssystem, mittels dessen wir uns eine fremde Sprache deuten" $"$.

Por outro lado, uma prática antropológica (auto)terapêutica, ao modo como prática Jeanne Favret-Saada, não possibilita instituir alguma distância entre si e o nativo e/ou entre si e si mesmo, pois o pesquisador/terapeuta precisa se inserir nos Sprachspiele, quer dizer, ele precisa se permitir ser enfeitiçado pelas performances e os usos da linguagem que se manifestam nas práticas. Tal processo, se dá em um exercício contínuo de seguir as regras, ou seja, seguir os padrões de correção das regularidades próprias das práticas culturais envolvidas para, assim, ser capaz de agir com coerência. Dito de outra maneira, é como se o último aforismo wittgensteiniano, ao qual aqui apresentamos, nos convocasse para compreender que o investigador - enquanto um estrangeiro em um processo de pesquisa antropológico (auto)terapêutico - admita que os modos de agir de uma dada forma de vida possuem desdobramentos específicos desta própria forma de vida. Desse modo, não há um invariante que perpassa todas as formas de vida, assim como não há um invariante que perpassa todos os Sprachspiele. "Um das Phänomen der Sprache zu beschreiben, muß man eine Praxis beschreiben, nicht einen einmaligen Vorgang, welcher Art immer es sei. Das ist eine sehr schwierige Erkenntnis. Die Sprache, mö̈hte ich sagen, berieht sich auf eine Lebensweise" ${ }^{47}$.

Para desenvolver esta perspectiva que desfigura a concepção de estar plenamente dentro ou fora das formas de vida, é preciso se deixar ser capturado (prise), ser orientado por algo que acontece no campo, onde as forças mágicas que ali circulam cobram sentido e não

\footnotetext{
${ }^{46}$ Tradução: "O modo de agir humano comum é o sistema de referência pelo qual interpretamos uma linguagem estranha”. (WITTGENSTEIN, 2017, \$206).

47 Tradução: "A linguagem, gostaria de dizer, se relaciona com um modo de vida. Para descrever o fenômeno da linguagem, temos que descrever uma práxis, não um processo singular de qualquer tipo que seja. Esta é uma realização muito difícil (WITTGENSTEIN, 2019, Parte VI, §34).
} 
significado $^{48}$. Com base em um olhar descritivo e terapêutico, Wittgenstein propõe que estes povos indígenas estão tão somente celebrando rituais. Desse modo, o que deveria ser de interesse do pesquisador, que se encontra em campo na atividade etnográfica, seria compreender os elementos que organizam as crenças - compreendendo que as crenças também orientam os sujeitos a agirem de uma forma ou de outra, concebendo as práticas por eles praticadas. Tendo isto em consideração, Wittgenstein propõe, então, uma "terapia filosófica" como possibilidade para pensar o campo para além das usuais dicotomias do pensamento ocidental.

Este modo de praticar a pesquisa e a filosofia se ocupa, primeiramente, em uma prática de desconstrução dos modos de agir dogmaticamente com a ciência moderna. Por isto, no prefácio às Investigações, Wittgenstein (2017, p. 6) dirá: “[...] pareceu-me dever publicar juntos aqueles velhos pensamentos [do Tractatus, R.P.C.] e os novos, pois estes apenas poderiam ser verdadeiramente compreendidos por sua oposição ao meu velho modo de pensar, tendo-o como pano de fundo" ${ }^{49}$. Em segundo lugar, Wittgenstein propõe uma virada antropológica que lida com o acaso no agir terapêutico do pesquisador em campo, tendo em vista que este não possui domínio das remissões analógicas quando ocupa um lugar no jogo concebendo as atividades do cotidiano que dizem respeito às ações práticas do homem.

Desse modo, ao perceber semelhanças em tonos diferentes entre Wittgenstein (2007; 2017) e Favret-Saada (1977), a pesquisa antropológica (auto)terapêutica que propomos ao colocar o trabalho de campo em questão, encara o campo sem uma pretensão de comprovar que os nativos possuem uma racionalidade subjacente à magia, diluindo o falso caráter de profundidade que emerge de uma má interpretação das formas da linguagem e que aparentam ser problemas profundos, pois “[...] es ist uns, als müßten wir die Erscheinungen durchschauen: unsere Untersuchung aber richtet sich nicht auf die Erscheinungen, sondern, wie man sagen könnte, auf die >Möglichkeiten <er Erscheinungen" ${ }^{\prime \prime 0}$.

No diálogo de Wittgenstein com a antropologia, emergente desse contato do filósofo com a obra de Frazer, deixa-se entrever a (auto)terapia como constitutiva do trabalho de campo, pois a entrada nos jogos faz com que assumamos que eles mesmos podem ser encarados como rituais que enfeitiçam e afetam. Assim, passamos a compreender que os nativos possuem rituais próprios que não clamam por uma explicaşão, ou mesmo, uma significação reduzida à outras formas de vida.

\footnotetext{
48 A dança da chuva, por exemplo, trata-se de um rito de alvorada, em honra ao Rei da Chuva Africano Mata Kodou. Este rito só é celebrado quando o sol está para nascer e não à noite, pois não haveria sentido enquanto celebração do que eles já sabiam que iria ocorrer em março, isto é: a chuva (ALMEIDA, 2007).

${ }^{49} \mathrm{Na}$ continuidade o filosofo afirma "Desde que comecei novamente a me ocupar há 16 anos com a filosofia, tive que reconhecer graves erros no que tinha colocado naquele primeiro livro. [...] Por mais de uma razão, o que aqui público vem ao encontro do que outros hoje escrevem. Minhas observações não carregam em si nenhuma estampa que as assinale como minhas, por isso não quero mais reivindicá-las também como minha propriedade. Eu as público com sentimentos dúbios. Não é impossível que a este trabalho, na sua indigência e na escuridão deste tempo, deva ser concedido lançar luz em um ou outro cérebro; mas, ainda assim, não é provável. Não quero economizar aos outros com meu escrito o pensar. Mas, se for possível, incitar alguém aos seus próprios pensamentos". (WITTGENSTEIN, 2017, pp. 6-7). Percebemos nesta escrita o esforço de Wittgentein em superar práticas de pesquisa verificacionistas, abrindo margem para um novo modo de agir, que o autor denominará 'terapia filosofia'.

50 Tradução: "Para nós é como se tivéssemos que ver através dos fenômenos: nossa investigação, no entanto, não se dirige aos fenômenos, senão, como se poderia dizer, às 'possibilidades' dos fenômenos. Quer dizer, nós repensamos o tipo de enunciados que fazemos sobre os fenômenos” (WITTGENSTEIN, 2017, §90).
} 
É dada a esta crítica levantada que podemos afirmar que Wittgenstein não está interessado em teses, mas em uma (auto)terapia que não busca promover a imposição unilateral de valores de uma forma de vida para outra, pois "[...] und wir dürfen keinerlei Theorie aufstellen. Es darf nichts Hypothetisches in unsem Betrachtungen sein. Alle Erklärung muß fort, und nur Beschreibung an ihre Stelle treten. Und diese Beschreibung empfängt ihr Licht, d.i.

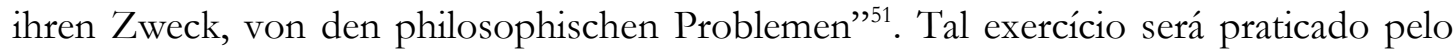
próprio Wittgenstein tanto nas Observacõoes sobre o Ramo Dourado de Frazer quando nas suas produções antropo/terapêutico filosóficas posteriores, onde ele se liberta de uma tendência dogmática. A grande lição é, portanto,

Das heißt, man könnte ein Buch über Anthropologie so anfangen: Wenn man das Leben und Benehmen der Menschen auf der Erde betrachtet, so sieht man, dass sie außer den Handlungen, die man tierische nennen könnte, der Nahrungsaufnahme, etc., etc., etc., auch solche ausführen, die eine ganz anderen //eigentümlichen// Charakter tragen und die man rituelle Handlungen nennen könnte. ${ }^{52}$ (WITTGENSTEIN, 2007, p. 198).

\section{Tono IV-Algumas considerações sem finais: uma melodia ressoa}

Em tempos e variações de espaço-tempo ínfimas, o que vemos é que, tanto em Favret-Saada quanto em Wittgenstein, as formas de vida - em suas heterogeneidades, dinâmicas e expressões - são assumidas como possibilidade de nos colocar enquanto investigadores em uma dimensão antropológica que assume a vida no (e com o) hasard. Isto porque o acaso, nos termos aqui problematizados, não guarda em si um potencial explicativo, mas, antes de qualquer coisa, uma potência produtora de sentidos, latentes no être affecté e nas Sprachspiele.

Guardando suas especificidades, Jeanne Favret-Saada e Ludwig Wittgenstein, provocam-nos a repensar, analisar e problematizar as práticas etnográficas assumidas no desenvolver do trabalho de campo nas pesquisas em Educação e Educação Matemática. Desde o être affecté aos Sprachspiele performados nas formas de vida, considerando suas instâncias filosóficas-epistemológicas-antropológicas, uma atitude metodológica vai se desenhando na cena de nosso ensaio musical, isto é, uma pesquisa antropológica (auto)terapêutica. Em uma atitude como esta, o pesquisador/terapeuta vai se apagando enquanto centralidade discursiva que estrutura a dualidade Eu/Outro, fazendo valer aquilo que acontece no campo, ou seja, um enfeitiçamento que acontece no (e com o) hasard.

Como proposto por nossos dois interlocutores, neste processo é produzido um desaparecimento (ou apagamento) das concepções que assumem o conhecimento como verdade absoluta, rompendo com práticas e estratégias etnográficas cientificistas que assumem uma dicotomia emic/etic- dicotomia esta que mina as possibilidades de estabelecer

\footnotetext{
51 Tradução: "Não pode haver nada hipotético em nossas observações. Toda explicação tem que sair, e colocar só a descrição no seu lugar. E essa descrição recebe sua luz, isto é, sua finalidade, dos problemas filosóficos" (WITTGENSTEIN, 2017, \$109).

52 Tradução: "Isto é, poder-se-ia começar um livro sobre antropologia assim: quando se considera a vida e a conduta do homem sobre a terra, é possível ver que, além do que se pode denominar atividades animais, a alimentação etc., etc., etc., há também realizações que carregam um Caráter totalmente outro //específico// e que se poderiam denominar ações rituais" (WITTGENSTEIN, 2007, p. 200).
} 
um Familienähnlichkeiten', pois, neste caso, o pesquisador/etnógrafo permanece em seu lugar, olhando a partir de suas lentes. Tal lugar, denominado por Favret-Saada como lugar ordinário, é orientado pelas regras gramaticais acadêmicas, isto é, estruturas linguísticas procuram pela localização e definição de um ' $E$ ' homogêneo, constituído a partir de técnicas que buscam visualizar e interpretar o Outro validando e legitimando a si mesmo um processo cientificista altamente narcísico.

Por outro lado, ao propor uma pesquisa antropológica (anto)terapêutica, defendemos que o trabalho de campo se constitui como uma prática terapêutica no (e com o) acaso. Nesta dimensão do trabalho de campo, o lugar que o pesquisador/(auto)terapeuta ocupa (sendo convidado a participar/ a entrar no jogo) é um lugar-afeç̧ão. Nele, como já problematizado neste texto, o acaso interrompe as tramas do possível como um fantasma do virtual e, em seus aparecimentos no real, povoam-nos, deslocam-nos, tocam-nos, desconstroem-nos, enfeitiçam-nos... abrindo brechas de sentidos nas bordas e criando margens de uma produção de si no (e com o) acaso - en y hasardant ma personne emergidos e submergidos nos Sprachspiele. Por isto, os "planos" que desejam descrever "o" acontecimento são desmanchados em uma aventura no (e com o) acaso, de uma força anônima que não sabemos de onde vem. O povoamento do acaso, por afecções que acontecem no campo, produz um fazer, nos termos mais artesanais que possa ser assumido, do pesquisador/ (auto)terapeuta (em termos metodológicos) e $o$ faz ao mesmo tempo (em termos ontológicos).

Desse modo, tanto as práticas produzidas pelo pesquisador/ (auto)terapeuta quanto a si mesmo acontecem ao mesmo tempo no encontro com o acaso, com as formas de vida; lugar-afecção onde avultam possibilidades de uma experimentação da vida a-significada, isto é, contra as explicações e generalizações homogêneas dos sentidos que fecundam o cientificismo etnográfico que opera de forma dogmática dentro dos Sprachspiele heterogêneos, sustentadores das formas de vida.

\section{Referências}

ALMEIDA, J. J. Apresentação: As IF como Obra Inacabada. In: WITTGENSTEIN, L. Investigações filosóficas. Philosophical Investigations. Edição, tradução e notas de João José de Almeida. 2007, pp. 307-349.

. Notas sobre as Observações sobre o ramo de ouro de Frazer. In:

WITTGENTEIN, L. Observações sobre o ramo de ouro de Frazer. Edição, tradução e notas de João José de Almeida. Introdução e revisão da tradução de Nuno Venturinha, Coordenação de Bruno Monteiro. : Deriva Editores, 2007, pp.-28-46. Disponivel em: http://www.psicanaliseefilosofia.com.br/adverbum/revistaadverbum.html

BARBOSA NETO, E. R. O quem das coisas: etnografia e feitiçaria em Les mots, la mort, les sorts. Horizontes Antropológicos, v. 18, n. 37, p. 235-260, jun. 2012.

http://www.scielo.br/scielo.php?script=sci arttext\&pid=S0104$\underline{71832012000100010 \& \operatorname{lng}=\text { en\&nrm }=\text { iso }}$ 
BARROS, M. C. D. M. Educação Bilíngüe, Llingüística e Missionários. Em Aberto, Brasília, ano 14, n. 63, jul./set. 1994.

FAVRET-SAADA, J. Désorceler. Paris: Éditions de l’Olivier, 2009.

Les mots, la mort, les sorts. Paris: Éditions Gallimard, 1977.

. "Ser afetado", de Jeanne Favret-Saada. Cadernos de Campo, São

Paulo, v. 13, n. 13, p. 155-161, 2005. Tradução Paula Siqueira.

FAVRET-SAADA, J.; CONTRERAS, J. Corps pour Corps. Enquête sur la sorcellerie dans le Bocage. Paris: Éditions Gallimard, 1981.

FIORI, A. L.; SERTÃ, A. L.; FERRARI, F.; DULLEY, I.; PINHEIRO DIAS, J.;

FERRITE, K.; VALENTINI, L.; SZTUTMAN, R.; NASCIMENTO, S.; MARRAS, S.

Sobre modos de se pensar e fazer antropologia: entrevista com Marilyn Strathern. Ponto Urbe, , 15 dez. 2015. Disponível em:

$<$ http://journals.openedition.org/pontourbe/2969>. Acesso em: janeiro de 2020.

GLISSANT, É. Le discours antillais. France: Gallimard, 1997.

GONDIM, D. M. O trabalho de campo na/para/com Etnomatemática como

possibilidade de uma pesquisa afecção: potências do devir. Bolema, Rio Claro, v. 34, n. 68, p. 1077-1104, dez. 2020. Disponível em <

$<$ http://www.scielo.br/scielo.php?script $=$ sci arttext\&pid $=$ S0103-

636X2020000301077\&lng=pt\&nrm=iso $>$. Epub 30-Nov-2020.

$<$ https://doi.org/10.1590/1980-4415v34n68a12> Acesso em 18 jan. 2021

GEERTZ, C. Observando o Islã - O Desenvolvimento Religioso no Marrocos e

na Indonésia. Tradução de Plínio Dentzien. Rio de Janeiro: Jorge Zahar Editor, 2004.

MARCUS, G.; CUSHMAN, D. Las Etnografías como Textos. In: REYNOSO, C. (ed.). E1 Surgimiento de La Antropología Posmoderna. Traducción de Carlos Reynoso. Barcelona: Gedisa, 2003. p. 171-213.

MATTOS, C. L. G. DE; CASTRO, P. A. de (Org.). Etnografia e educação: conceitos e usos. Campina Grande: eduepb, 2011.

PARRA, A.; TAMAYO, C. Problematizando las relaciones de saber/poder de la Etnografía en la Etnomatemática. In: 6TO CONGRESO INTERNACIONAL DE ETNOMATEMÁTICA, , Colômbia. Anais em edicação. Colômbia: 2018.

PIKE, K. L. Language in relation to a unified theory of the structures of human behavior. 2. ed. The Hague: Mouton, 1967. 
STRATHERN, M. O efeito etnográfico e outros ensaios. Tradução Iracema Dulley, Jamille Pinheiro e Luísa Valentini. São Paulo: Cosac Naify, 2014.

TAMAYO-OSORIO, C. Venha, vamos balançar o mundo, até que você se assuste: uma terapia do desejo de escolarização moderna. 2017. 295 f. Tese (Doutorado em Educação) - Universidade Estadual de Campinas, Faculdade de Educação. Campinas, 2017.

WITTGENSTEIN, L. Tractatus Logico-Philosophicus. Repr. 1994. Editora USP, São Paulo: 1918.

Investigações filosóficas. Philosophical Investigations. Edição, tradução e notas de João José de Almeida. 2017. Disponivel em: < http://www.psicanaliseefilosofia.com.br/textos.html>

Observaciones sobre los fundamentos de la matemática. Edição, tradução e notas de João José de Almeida. 2019. Disponivél em: <http://www.psicanaliseefilosofia.com.br/textos.html>

Observações sobre o ramo de ouro de Frazer. Edição, tradução e notas de João José de Almeida. Introdução e revisão da tradução de Nuno Venturinha, Coordenação de Bruno Monteiro. Deriva Editores. 2007. < http://www.psicanaliseefilosofia.com.br/textos.html> 